Dr Vladan Stanojev

\title{
PRIMENA NOVIH NAČINA ZA UTVRĐIVANJA ODLUČNIH ČINJENICA**
}

U proteklih dvadesetak godina, kako praksa ukazuje, najveći procenat utvrđenih odlučnih činjenica u prekršajnim postupcima baziran je na iskazu okrivljenog čiji je iskaz ocenjen kao njegovo priznanje ili na bazi iskaza saslušanog svedoka (najčešće ovlašćenog inspektora, koji je svoj iskaz zasnovao na neposrednom opažanju). Međutim, imajući u vidu da je oduvek najveći procenat otkrivenih prekršaja bio iz oblasti bezbednosti saobraćaja, postepeno su prilikom otkrivanja prekršaja počeli da se koriste i tehnički uređaji. Među njima je prvi bio fotoaparat.

Na osnovu izučavanja uzroka velikog broja saobraćajnih nezgoda došlo se do saznanja da su najčešći uzročnici saobraćajnih nezgoda vožnja motornim vozilom pod dejstvom alkohola ili upravljanje motornim vozilom neprilagođenom brzinom stanju puta i uslovima saobraćaja. Kod ovih prekršaja su počela da se iznalaze tehnička rešenja kako bi odgovarajući uređaji i aparati pomogli u dokazivanju ovih vrsta prekršaja. Tako su se i pojavili prvi radari kojima se merila brzina kretanja vozila na putevima, kao i prvi alkohometri - sprave za merenje količine alkohola u organizmu vozača. Uvedeni su Doplerovi radari kojima je policija utvrđivala brzinu kretanja vozila, kao i čuveni alkotest aparati marke dreger.

* Rad je primljen: 24. 04. 2009.

** Deo doktorskog rada pod nazivom „POLOŽAJ I ULOGA INSPEKCIJSKIH ORGANA UPRAVE U PREKRŠAJNOM POSTUPKU”. 
Profesor I. Feješl ukazuje da je savremeni kriminalitet, pod kojim podrazumeva i prekršaje, izuzetno dinamična i složena masovna društvena pojava. Suzbijanje kriminaliteta zahteva razradu strategije koja će se zasnivati na naučno zasnovanom sistemu preventivnih i represivnih mera u okviru kojih će krivično-pravna sredstva imati adekvatno mesto. U današnjim uslovima, efikasan može biti samo integralni program sa razrađenom strategijom, od prvog zahvata do pravosnažne presude, sa osloncem na nauku i razvijen u strogo zakonskim okvirima. Savremena nauka će morati da ima značajniju ulogu u tome, a posebno prirodno-tehničke nauke koje će pomoći u otkrivanju krivičnih dela, prekršaja i drugih štetnih ponašanja za koje su propisane odgovarajuće sankcije. Kriminalistika, sa osloncem na prirodno-tehničke i druge nauke, razvija nove metode i sredstva mnogo bržim tempom nego što to zakonodavna vlast može da prati. Veliki broj ovih sredstava i metoda su veoma efikasna sredstva otkrivanja krivičnih dela i prekršaja i njihovih učinilaca, ali isto tako mogu biti pogodna za razne zloupotrebe koje se ogledaju u neovlašćenom zadiranju u ljudska prava.

U okviru ovog pitanja daje se kratak osvrt na moderne uređaje koji se trenutno koriste $u$ otkrivanju pojedinih vrsta prekršaja i rezultati, odnosno analiza više snimaka urađenih u otkrivanju saobraćajnih prekršaja od strane saobraćajne policije SUP-a Novi Sad, kao i snimaka koje je autor ovog rada lično napravio u cilju prikazivanja efikasnosti tehničkih uređaja u otkrivanju određenih vrsta prekršaja i pružanju teško oborivih dokaza pred prekršajnim organima.

\section{Utvrđivanje brzine kretanja motornih vozila}

$\mathrm{Na}$ osnovu višegodišnjih podataka o uzročnicima saobraćajnih nezgoda, može se videti da se brzina kretanja, odnosno neprilagođena brzina, i prekoračenje dozvoljene brzine nalaze na prvom mestu na listi uzročnika nezgoda. Zakon o osnovama bezbednosti saobraćaja na putevima predviđa u tom pravcu rigorozne prekršajne sankcije, a one se ogledaju u sledećem:

U članu 226. stav 1. tačka 4. Zakona o osnovama bezbednosti saobraćaja na putevima propisana je novčana kazna od 5.000,00 do 25.000,00 dinara ili kazna zatvora do 60 dana ako se u naseljenom mestu prekorači brzina za preko $30 \mathrm{~km} / \mathrm{h}$ od dozvoljene, odnosno van naseljenog mesta za više od $50 \mathrm{~km} / \mathrm{h}$ preko dozvoljene brzine. Za navedeni prekršaj prema stavu 2. istog člana predviđeno je i obavezno izricanje zaštitne mere „zabrane upravljanja motornim

${ }^{1}$ Feješ, I., Savremeni kriminalitet $i$ dokazno pravo, Novi Sad, Pokrajinski sekretarijat za obrazovanje i kulturu, 2002, str. 13. 
vozilom odgovarajuće kategorije u trajanju od 3-12 meseci”. Ako je ovakvim prekoračenjem prouzrokovana saobraćajna nezgoda bez obeležja krivičnog dela ugrožavanja bezbednosti saobraćaja, tada je kao sankcija predviđena novčana kazna od 12.000,00 - 50.000,00 dinara ili kazna zatvora od 30-60 dana, uz obavezno izricanje zaštitne mere zabrane upravljanja motornim vozilom odgovarajuće kategorije u trajanju od tri meseca do jedne godine. Dakle, vidi se da je u ovim situacijama predviđena mogućnost izricanja kazne zatvora do 60 dana ako su delom prouzrokovane teže posledice ili postoji veći stepen odgovornosti učinioca.

U članu 228. stav. 1. tačka 3. Zakona o osnovama bezbednosti saobraćaja na putevima predviđeno je sankcionisanje prekoračenja brzine u naseljenom mestu i to za preko $10-30 \mathrm{~km} / \mathrm{h}$, odnosno van naseljenog mesta od $30-50 \mathrm{~km} / \mathrm{h}$, i to sa novčanom kaznom od 3.000,00 dinara koja je predviđena da se naplaćuje na licu mesta. Ako je ovim prekoračenjem prouzrokovana saobraćajna nezgoda, stavom 2. ovog člana propisana je novčana kazna od 4.000,0030.000,00 dinara ili kazna zatvora do 60 dana sa mogućnošću izricanja zaštitne mere zabrane upravljanja motornim vozilom određene kategorije u trajanju od 30 dana do 6 meseci.

Prema članu 229. stav 1. tačka 7. Zakona o osnovama bezbednosti saobraćaja na putevima, sankcionisano je prekoračenje dozvoljene brzine u naseljenom mestu do $10 \mathrm{~km} / \mathrm{h}$ i van naseljenog mesta od $10-30 \mathrm{~km} / \mathrm{h}$ novčanom kaznom od 2.000,00 dinara koja se naplaćuje na licu mesta. Prema stavu 2. istog člana, ako je ovakvim prekoračenjem izazvana saobraćajna nezgoda tada je predviđena novčana kazna od 3.000,00-25.000,00 dinara ili kazna zatvora do 40 dana sa mogućnošću i izricanja zaštitne mere zabrane upravljanja motornim vozilom određene kategorije u trajanju od 30 dana do 3 meseca.

Da bi se utvrdila odlučna činjenica prekoračenja brzine kao obeležje prekršaja, uvek je neophodno koristiti odgovarajuće merne instrumente. Do pre pet-šest godina koristili su se u većini slučajeva Doplerovi radari koji su precizno merili brzinu kretanja i to samo jednog vozila u koje je radar usmeren i pod strogim meteorološkim uslovima i pravilima korišćenja koji su se odnosili na to, tako da se brzina mogla utvrđivati jedino u odlasku vozila. Osnovni problem u dokazivanju prekršaja korišćenjem Doplerovih radara sastojao se u tome što su okrivljeni često izražavali sumnju da su se kretali u koloni vozila i da je baš radar bio usmeren u njihovo ili drugo vozilo, a s obzirom na to da se na displeju radara očitavala samo izmerena brzina vozila u koje je radar u određenom trenutku bio usmeren. Ove okolnosti su se morale proveravati saslušanjem svedoka - policajca, koji je koristio odgovarajući radarski uređaj. 
Prilikom ispitivanja ovih svedoka, od strane okrivljenih izražavala se sumnja da je brzina utvrđena za neko drugo vozilo koje se na istom mestu navodno brže kretalo od vozila okrivljenog.

Sudijama za prekršaje je u takvim situacijama jedino ostajalo da poveruju iskazu policajca - inspektora, obrazlažući izbor samo jednog vozila za utvrđivanje brzine kao diskreciono pravo ovlašćenog službenog lica i tehničkim manama ovakvih uređaja (da ne mogu meriti brzinu svih vozila, već samo jednog u određenom trenutku). Najpoznatiji Doplerov radar je čuveni K-15, za koga se uvek moralo i pribavljati odgovarajuće uverenje o tehničkoj ispravnosti, kao i za sve druge merne instrumente za odgovarajuću kalendarsku godinu. Za ove uređaje treba reći da su se u svetu prilikom njihovog korišćenja pojavljivali i odgovarajući radarski detektori koji su se koristili od strane vozača, kako bi se u blizini kretanja vozila otkrio radarski uređaj preko zraka koje je on emitovao.

Sa napretkom tehnike pojavili su se novi merni uređaji kojima se merila brzina, a koji su napustili prevaziđenu radarsku tehnologiju i baziraju se na laserskom merenju brzine i udaljenosti vozila. Tako se kod nas, prvi put pre šest godina pojavljuju u upotrebi uređaji „PRO LASER III“.

Karakteristike ovih uređaja su sledeće:

- to je univerzalni uređaj koji meri daljinu i brzinu kretanja odabranih ciljeva putem laserskog zraka,

- uređaj je potpuno nevidljiv za klasične radarske detektore koje koriste vozači,

- uređaju se može pridodati digitalni fotoaparat,

- snimanje prekršioca vrši se kroz tražilo fotoaparata koje je povezano sa optičkim okvirom laserskog uređaja,

- mrežica za ciljanje određenog vozila i brzina prekršioca su prikazani na fotografiji, a datum i vreme se mogu obezbediti na fotografiji,

- sistem sadrži LCD monitor na zadnjem delu fotoaparata radi provere fotografije i lakšeg pregledanja snimka, i

- fotografije se mogu štampati na printeru ili mogu biti odštampane kad se prenesu na personalni računar.

Najsavremeniji novi uređaj u svetu, pa i kod nas je „FAMA LASER III”. Osnovna karakteristika ovog uređaja je ta da je snabdeven video kamerom, odnosno video uređajem sa velikom rezolucijom u boji koji pravi video zapis čitavog kretanja vozila na određenom prostoru, sa mogućnošću da na licu mesta reprodukuje video snimak sa kretanjem vozila, njegovom izmerenom brzinom i prepoznavanjem registarskih tablica sa velike udaljenosti. Ovaj uređaj u odnosu na druge ima mogućnost i merenja brzine u pokretu, što znači da se može 
koristiti i u službenom vozilu u pokretu. Uređaj ima takođe mogućnosti da registruje i druge događaje osim prekoračenja brzine, na primer: nepropisno preticanje, nepropisno zaustavljanje i parkiranje, nezaustavljanje na znak crvenog svetla, neustupanje prvenstva prolaza pešacima od strane vozila i uviđaje i dr.

Pored toga „FAMA LASER III” pravi video zapis svih podataka koji su potrebni za dokazivanje saobraćajnog prekršaja kao što su: godina, mesec, dan, sat, minut, sekunde, signal nišana, režim merenja, merna brzina $\mathrm{u} \mathrm{km} / \mathrm{h}$, merna udaljenost u metrima, prečnik laserskog snopa na mernoj udaljenosti, redni broj video zapisa, granična brzina identifikatornog uređaja, podaci o geografskoj širini i dužini u stepenima i minutima, audio vizuelne okolnosti saobraćajnog prekršaja i motorno vozilo sa jasno vidljivim registarskim tablicama i likom samog vozača.

Tehničke karakteristike opisanog uređaja su takve da može meriti brzinu u opsegu od 0-400 km/čas. Vreme prikazivanja rezultata merenja je od $0,3-$ 1 sekunde. Temperaturni opseg rada je od $-5^{\circ} \mathrm{C}$ do $+40^{\circ} \mathrm{C}$. Uređaj ima kolor LCD monitor sa video zapisom na odgovarajućoj kaseti. Najznačajnije su ipak dve karakteristike: merenje brzine kretanja se vrši na udaljenosti do maksimalnih $1.800 \mathrm{~m}$, tako da vozač ne može da primeti službeno vozilo sa ovim uređajem i tačnost merenja je u toleranciji od $\pm 0,2 \mathrm{~m}$.

$\mathrm{Na}$ osnovu izloženih karakteristika pomenutog mernog instrumenta, vidi se da on otklanja sve negativne karakteristike Doplerovih radara i obezbeđuje postupajućem sudiji za prekršaje video zapis kretanja vozila okrivljenog sa tačno očitanom brzinom na određenoj udaljenosti i u određenom vremenu, sa mogućnošću da i okrivljeni sam neposredno nakon kontrole može da vidi kretanje vozila sa kojim je upravljao na određenom delu puta, kao i sebe za upravljačem.

U razgovoru sa pripadnicima saobraćajne policije, kao i sudijama za prekršaje, došao sam do saznanja da kontrolisani vozači posle pokazivanja reprodukovanih snimaka kretanja njihovog vozila ni u jednom slučaju nisu osporavali prekoračenje brzine, već su nastojali da izmole izricanje što blaže sankcije, a pogotovo da im se, ako je to moguće uslovi zaštitna mera zabrana upravljanja motornim vozilom a koja je za drastično prekoračenje brzine i obavezna. Ne treba zaboraviti ni činjenicu da se prezentovanjem video zapisa dolazi do priznanja prekršaja bez potrebe izvođenja drugih dokaza, što u velikoj meri doprinosi efikasnosti prekršajnog postupka. Osim toga, video zapis pruža mogućnosti postupajućem sudiji za prekršaj ili saobraćajnom policajcu da sazna i druge okolnosti kod ove vrste prekršaja, a to je na primer da li je prekršaj učinjen u blizni pešačkog prelaza, škole i slično. 
U ovom poglavlju daje se nekoliko karakterističnih inserata, sa video zapisa saobraćajne policije (koji se daje kao prilog ovog rada) a koji se odnose na prekoračenja brzine, kao i statistički podaci sa video zapisa.

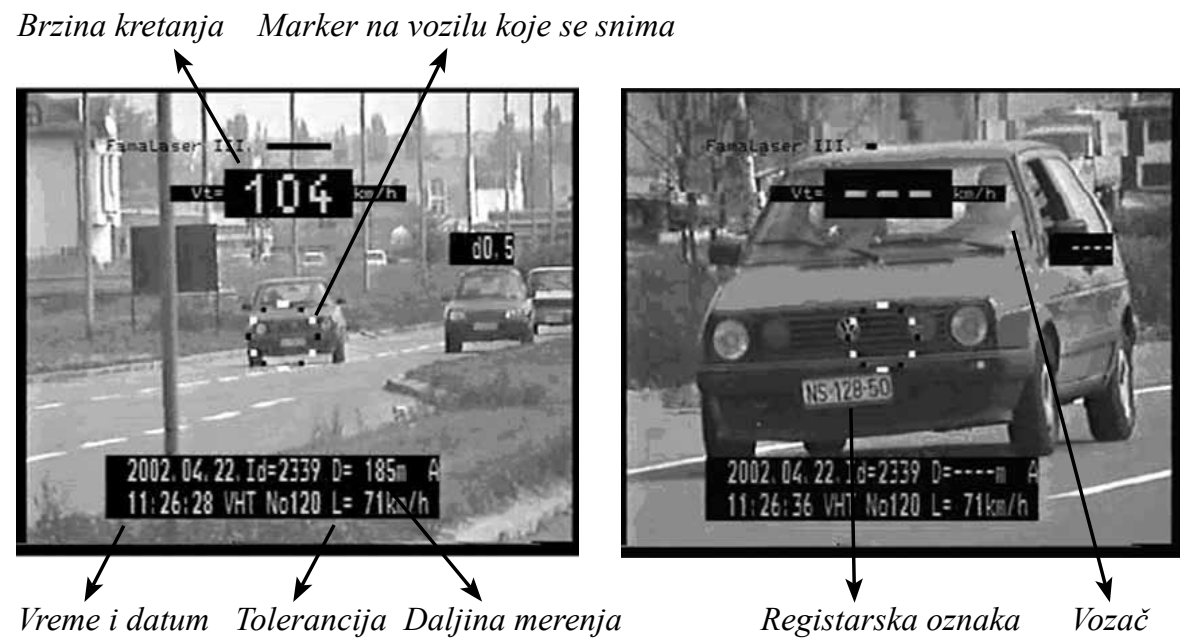

Objašnjenje uz slike:

$\mathrm{Na}$ ovim snimcima se vidi putničko vozilo registarski br. NS 128-50 koje je u Novom Sadu, na Veterničkom putu, u naseljenom mestu, prekoračilo brzinu za $44 \mathrm{~km} / \mathrm{h}$ jer je na ovom delu puta dozvoljena brzina kretanja ograničena na $60 \mathrm{~km} / \mathrm{h}$. U ovoj situaciji se radi o osnovanoj sumnji da je vozač učinio prekršaj iz člana 226. stav 1. tačka 4. Zakona o osnovama bezbednosti saobraćaja na putevima. Za ovaj prekršaj je predviđena novčana kazna od 5.000,00 do 25.000,00 dinara ili kazna zatvora do 60 dana uz obavezno izricanje zaštitne mere zabrane upravljanja motornim vozilom „B” kategorije u trajanju od tri do šest meseci. Interesantno je napomenuti da u pojedinim slučajevima vozači videvši ovo prekoračenje brzine koje su počinili nude da plate kaznu na licu mesta, a što nije dozvoljeno, jer za ovaj prekršaj nije predviđena novčana kazna u fiksnom iznosu. Ovaj video zapis može da posluži i rukovodećim radnicima u policijskim stanicama da sravne prekršajne prijave sa ovim zapisima, koji se inače na licu mesta ne mogu brisati, a sve u cilju da se spreče eventualne zloupotrebe bilo koje vrste od strane pripadnika saobraćajne policije.

Objašnjenje uz sledeće slike: Na ovom delu puta, odnosno u ulici Rumenački put u Novom Sadu, ograničenje brzine kretanja motornih vozila je 60 $\mathrm{km} / \mathrm{h}$, što znači da je u ovoj situaciji vozač putničkog motornog vozila prekoračio brzinu kretanja za 16 km/h, čime je učinio prekršaj iz člana 228. stav 1. 

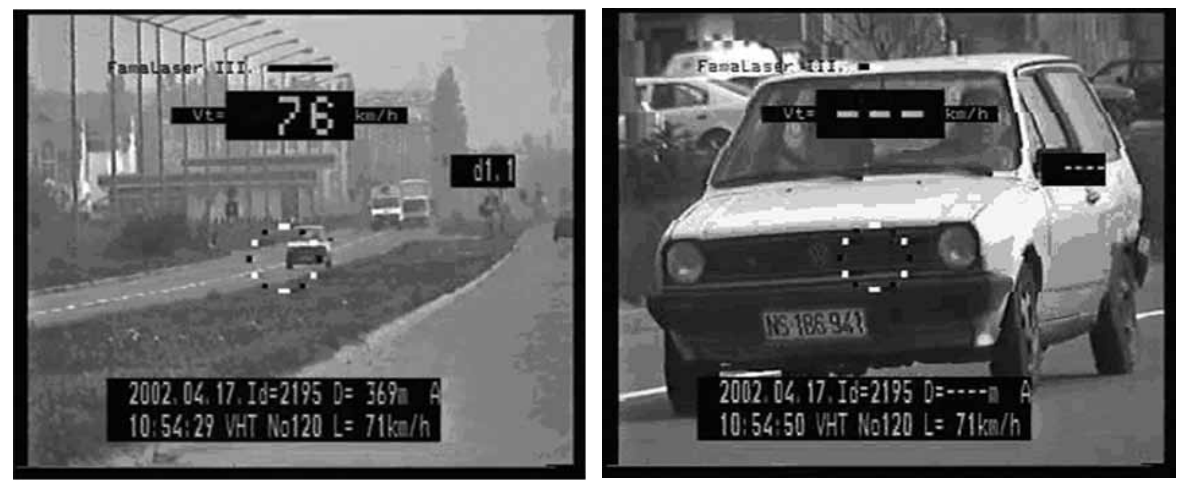

tačka 3. Zakona o osnovama bezbednosti saobraćaja na putevima, za koji je propisana novčana kazna u fiksnom iznosu od 3.000,00 dinara koja se naplaćuje na licu mesta. Kontrolisanom licu se mora ponuditi da plati novčanu kaznu na licu mesta ili u ostavljenom roku, a u protivnom se mora podneti zahtev za pokretanje prekršajnog postupka koji se vodi u stanici policije.

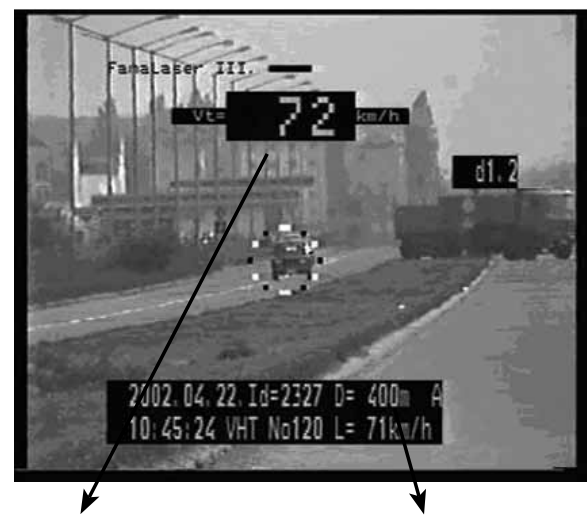

Brzina kretanja

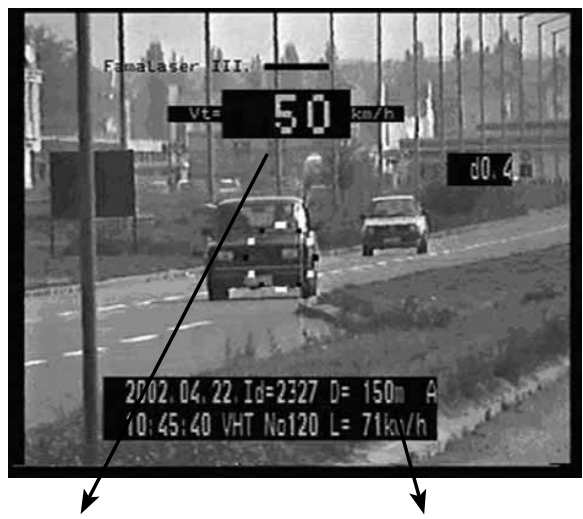

Brzina kretanja

Udaljenost $150 \mathrm{~m}$

Objašnjenje uz slike: Na ovim slikama se vidi kretanje putničkog vozila na različitim udaljenostima, kao i činjenica da je vozač ovog vozila u naseljenom mestu na udaljenosti od $400 \mathrm{~m}$ od saobraćajne policije prekoračio dozvoljenu brzinu od $12 \mathrm{~km} / \mathrm{čas} \mathrm{i}$ da je na udaljenosti od $150 \mathrm{~m}$ verovatno primetio vozilo saobraćajne policije pa je naglo usporio kretanje vozila. Ovde se radi o prekršaju iz čl. 228. stav 1. tačka 3. Zakona o osnovama bezbednosti saobraćaja na putevima, i predviđena je novčana kazna u fiksnom iznosu od 3.000,00 dinara koja se naplaćuje na licu mesta. 

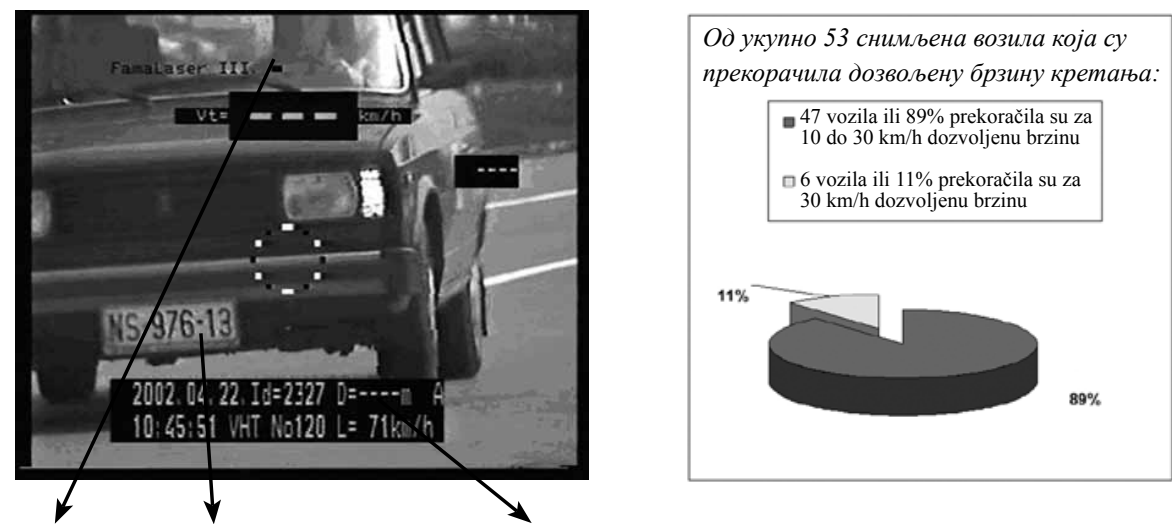

Vozač i registarska tablica Neposredno ispred kamere

Grafikon broj 1

Sumirajući video zapis, sastavljen je grafikon broj 1 koji ukazuje na visinu prekoračenja brzine vozila u naseljenim delovima Novog Sada.

\section{Utvrđivanje drugih činjenica i okolnosti}

Prilikom snimanja ulica odnosno saobraćajnica, bilo da se radi o video zapisu ili fotografijama, može da se dođe do niza podataka odnosno činjenica koje mogu da posluže za utvrđivanje obeležja pojedinih prekršaja. Na fotografiji koja sledi vidi se jedna od najprometnijih ulica u Novom Sadu (Jevrejska ulica) u kojoj je velika frekvencija saobraćaja. Ova ulica ima magistralni karakter i u njoj je veliki promet vozila i gustina pešaka, zbog blizine pijace i

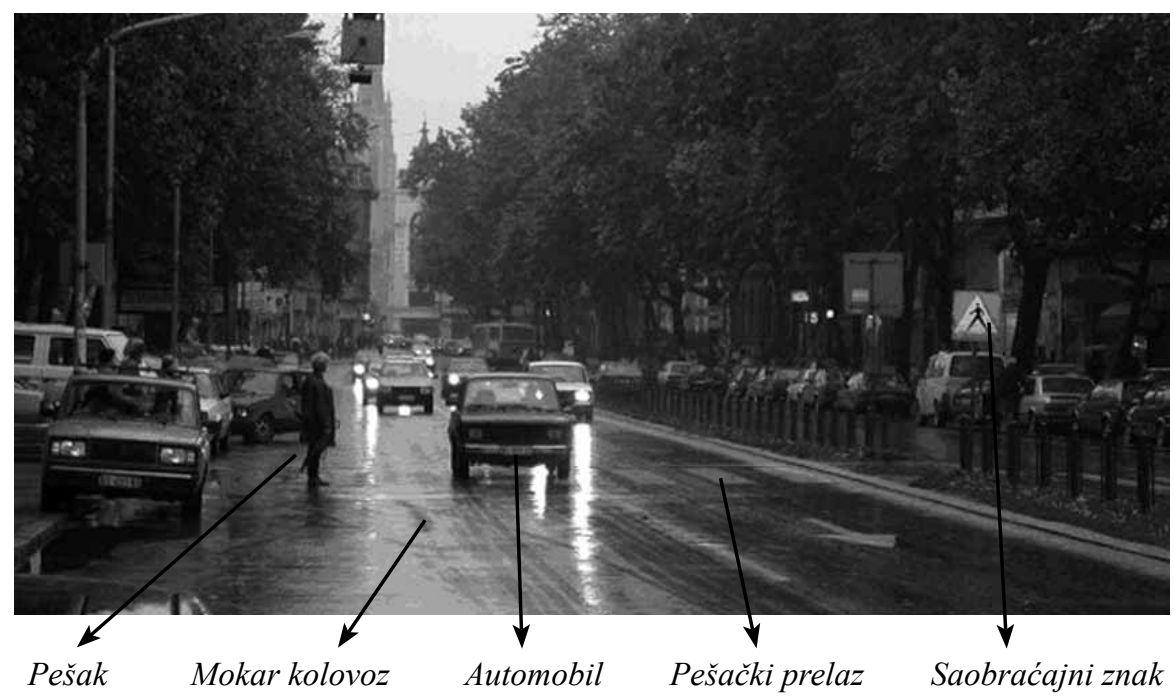


obližnjih škola. Snimak pokazuje pešaka koji je stupio na pešački prelaz, a što zahteva od vozača motornog vozila da se zaustavi ispred pošačkog prelaza. Kao važna činjenica zapaža se mokar kolovoz koji zahteva opreznu vožnju i prilagođavanje kretanja vozila ovom uslovu. Vidi se i saobraćajna signalizacija i saobraćajni znaci, kao i nepropisno parkirana vozila koja mogu uticati na bezbednost pešaka i ostalih učesnika u saobraćaju.

Snimci koji slede sačinjeni su prilikom uviđaja saobraćajne nezgode u kojoj su učestvovala dva putnička vozila. Na prvoj i drugoj slici vidi se mesto kontakta putničkih vozila na kolovozu sa obe strane ulice.
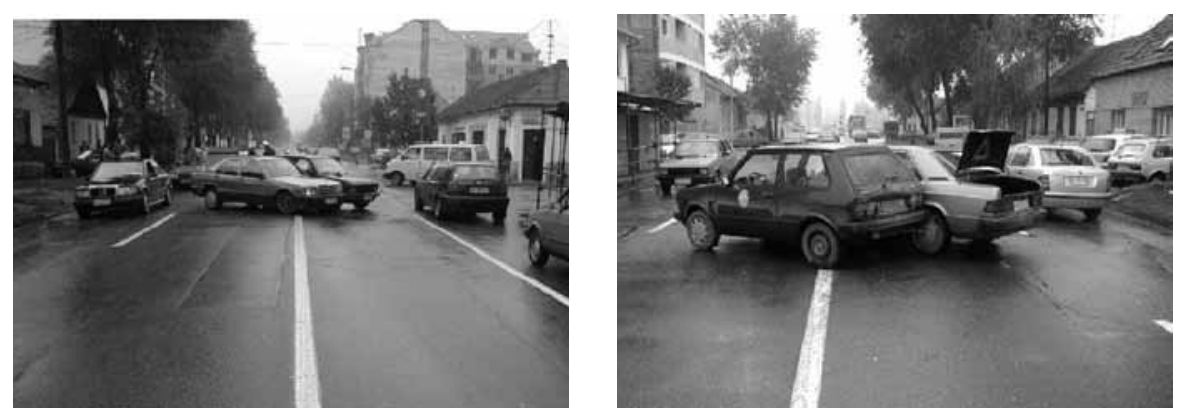

Ove fotografije ukazuju na mogući uzrok ove saobraćajne nezgode, a to je nepropisno uključivanje u saobraćaj jednog od vozila (putničko vozilo marke „mercedes”).

$\mathrm{Na}$ fotografijama koje slede zabeležena su oštećenja na vozilima. Vidi se da je putničko vozilo marke ,jugo", svojim prednjim, desnim bočnim delom udarilo u levu bočnu stranu vozila „mercedes” koji se uključivao u saobraćaj u levu saobraćajnu traku, i to nepropisno. Vozač vozila „mercedes” nije se prethodno uverio da radnju uključivanja vozila u levu saobraćajnu traku može izvesti bez opasnosti po ostale učesnike u saobraćaju.
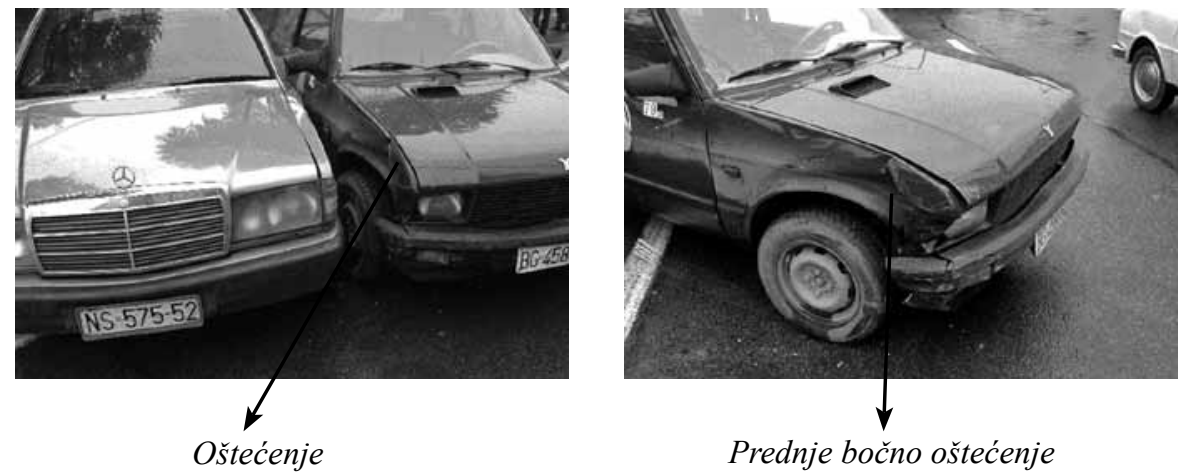
Ovde nije potrebno veštačenje, jer iskusni sudija za prekršaje na osnovu položaja vozila i oštećenja na vozilima može lako da utvrdi čijom nepropisnom radnjom je došlo do nezgode, odnosno ko je odgovoran za prekršaj. Radi se o prekršaju iz člana 227. stav 2. u vezi sa stavom 1. tačka 4. Zakona o osnovama bezbednosti saobraćaja na putevima, za koji je propisana novčana kazna od 8.000,00 do 40.000,00 dinara uz mogućnost izricanja zaštitne mere zabrane upravljanjem motornim

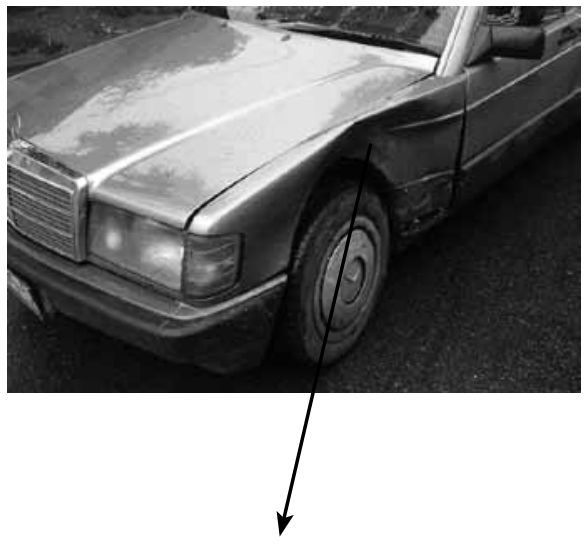

Bočno oštećenje vozilom u trajanju od 30 dana do 6 meseci.

$\mathrm{Na}$ fotografijama koje slede uočavaju se dva prekršaja. To su nepropisno parkirano vozilo i nepropisno kretanje vozila unazad, u ulici Železničkoj u Novom Sadu. Za nepropisno parkiranje predviđena je kazna u fiksnom iznosu od $2.000,00$ dinara prema članu 229. stav 1. tačka 14. Zakona o osnovama bezbednosti saobraćaja na putevima. Ovo se odnosi na vozača putničkog vozila registarskog broj NS 632-98.

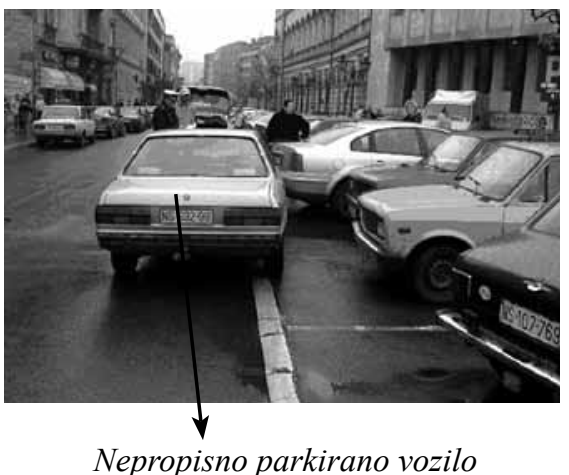

Nepropisno parkirano vozilo

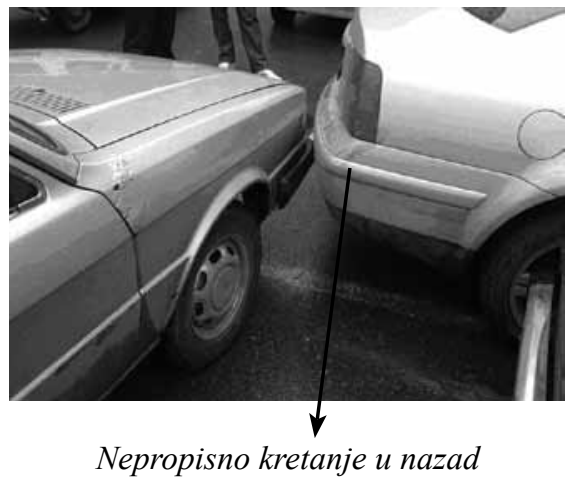

Nepropisno kretanje u nazad

Za nepropisno kretanje vozila unazad, koje ima za posledicu saobraćajnu nezgodu, propisana je novčana kazna od 2.500,00 do 20.000,00 dinara ili kazna zatvora prema članu 230. stav 2. u vezi sa stavom 1. tačka 5. Zakona o osnovama bezbednosti saobraćaja na putevima. Ovo se odnosi na vozača putničkog vozila koji je pokušao da se vožnjom unazad uključi u saobraćaj i tom prilikom je izazvao saobraćajnu nezgodu. 


\section{Višekratno snimanje pružnog prelaza}

Statistički podaci Ministarstva unutrašnjih poslova pokazuju da je u Republici Srbiji na preko $5.500 \mathrm{~km}$ pruge sa 2.375 putnih prelaza za poslednjih sedam godina na ovim prelazima, odnosno ukrštanjima pruge i puteva, poginulo 120 ljudi kao i da se desilo na stotine saobraćajnih nezgoda. Zbog toga se pojavila potreba da se i ovi podaci bliže analiziraju i izuči ova pojava. U tom pravcu je izrađeno više video snimaka na pružnim prelazima.

Analizirajući više snimaka u trajanju od 42 do 45 minuta, koje sam uradio na teritoriji grada Novog Sada, na pružnom prelazu kod Sremske Kamenice, i gde postoji saobraćajni znak „STOP” (obavezno zaustavljanje), došao sam do zaključka da se u većini slučajeva vozači motornih vozila nisu zaustavili ispred znaka, niti su usporili kretanje svog vozila. To je preciznije prikazano na tri naredna grafikona.

Iz ovog grafikona se vidi da se 21 . juna 2006. godine za vremenski period od 42 minuta samo jedno putničko vozilo zaustavilo ispred saobraćajnog znaka, dok se 108 vozila uopšte nije zaustavilo, a 82 vozila je samo usporilo kretanje. Samo $1 \%$ vozača motornih vozila je poštovalo saobraćajni znak.

Iz sledećeg grafikona vidi se da se dana 22. juna 2006. godine u vremenu od 45 minuta nijedno vozilo nije zaustavilo ispred saobraćajnog znaka, tj. obeleženog pružnog prelaza.

Na bazi podataka od 23. juna 2006. godine (grafikon br. 4), odnosno snimka od 45 minuta, vidi se da je 89 vozila samo usporilo, dok se njih 119 nije zaustavilo niti su usporili ispred saobraćajnog znaka „STOP”. Dakle, ukupno je samo za ovo

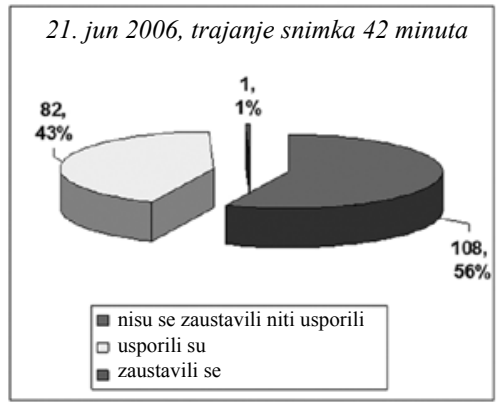

Grafikon broj 2

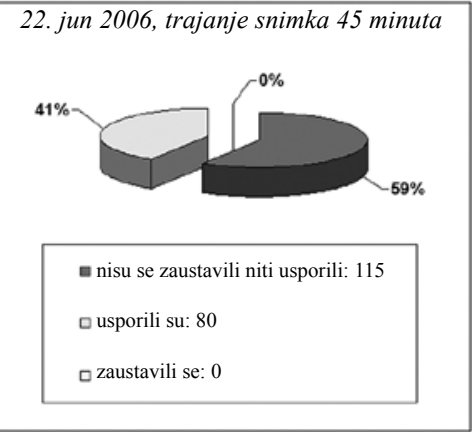

Grafikon broj 3

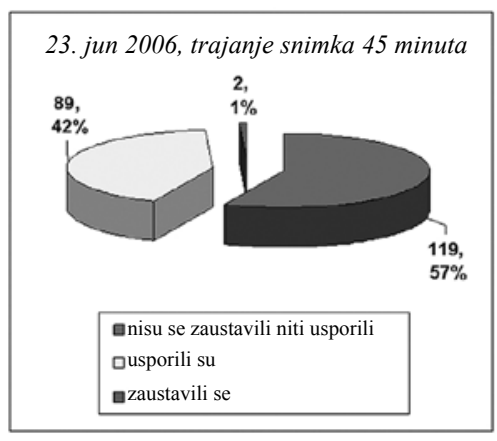

Grafikon broj 4 
kratko vreme za 208 lica utvrđeno da su učinili prekršaj za koji je propisana mandatna kazna od 2000,00 dinara.

Da je umesto autora ovog rada na ovom mestu stajao policajac - saobraćajni inspektor, mogao je da naplati ukupno 416.000,00 dinara novčane kazne. Koliki bi tek efekat bio kad bi se ovde kontrola vršila neprekidno 24 sata. Nedvosmisleno je da ova situacija pokazuje da bi se sankcionisanjem ovakvih i sličnih prekršaja, pored nespornog finansijskog efekta u budžetu Republike Srbije, postigli efekti u sprečavanju krivičnih dela ugrožavanja bezbednosti saobraćaja sa poginulima i povređenima i velikom materijalnom štetom kao posledicom, o čemu je već bilo reči.

Za nepostupanje po saobraćajnom znaku prema članu 229. stav 1. tačka 33. Zakona o osnovama bezbednosti saobraćaja na putevima predviđena je novčana kazna koja se naplaćuje na licu mesta od 2.000,00 dinara. Ako je prouzrokovana saobraćajna nezgoda, tada je propisana novčana kazna u rasponu od 3.000,00 do 25.000,00 dinara ili kazna zatvora od 40 dana sa mogućnošću izricanja zaštitne mere zabrane upravljanja motornim vozilom za period od 30 dana do 3 meseca.

U nastavku ovog teksta daju se i dva karakteristična inserta iz napravljenog video zapisa.

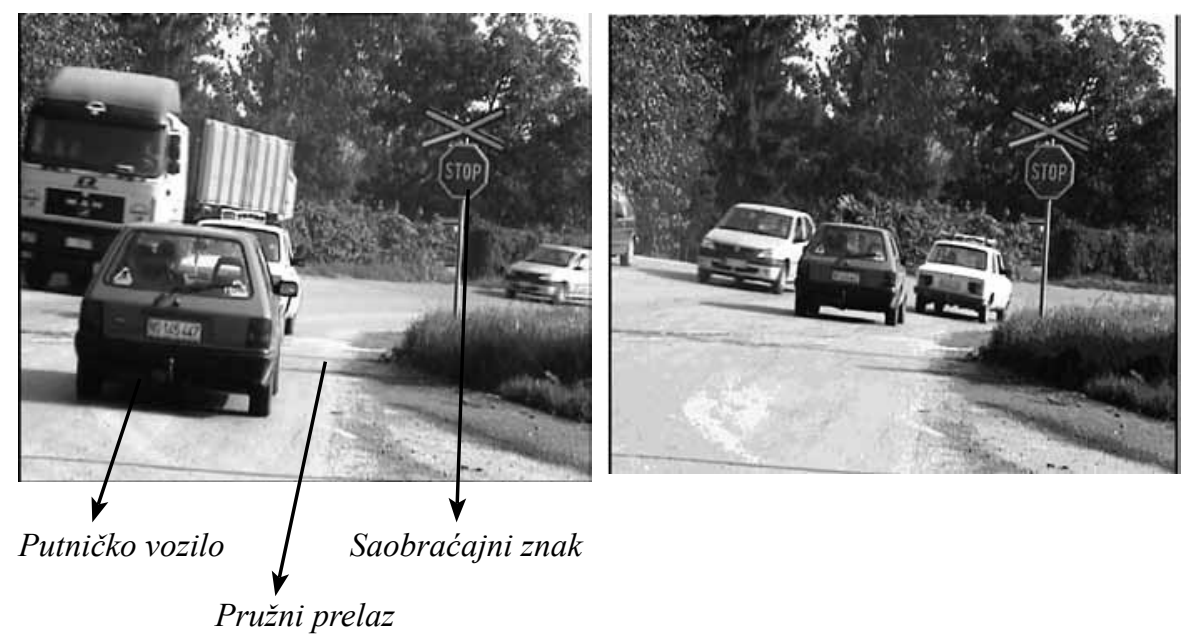

Putničko vozilo nije se zaustavilo ispred znaka „STOP”, niti je usporilo ispred istog znaka. 